\title{
The Second International: The Impact of Domestic Factors on International Organization Dysfunction
}

Article in Political Studies · August 2013

DOI: $10.1111 / 1467-9248.12062$

CITATIONS

0

2 authors, including:

\section{Kursat Cinar}

Bilkent University

8 PUBLICATIONS 10 CITATIONS

SEE PROFILE
READS

11

Some of the authors of this publication are also working on these related projects:

Political trust around the world View project 


\title{
The Second International: The Impact of Domestic Factors on International Organization Dysfunction
}

\author{
Meral Ugur Cinar Kursat Cinar \\ Bilkent University \\ Ohio State University
}

This article explores the role of domestic factors in international organization dysfunction, exemplified by the failure of the Second International to agree on a common stance and policy for the prevention of the First World War. Focusing on the French and German socialist parties, the two most powerful forces in the Second International, it assesses how domestic factors, such as differences in the dependency on the electorate, internal party structure and party-trade union relationships affected the policy preferences of these socialist parties. It concludes that these domestic differences were the source of discrepancy and lack of orchestrated action among the members of the Second International. As a result of these differences, the Second International failed to coordinate and produce a binding resolution that would commit its members to a uniform action against war, hence culminating in international organization dysfunction.

Keywords: Second International; international organizations; domestic factors; IOs; Europe

In the years preceding the First World War, the Second International ${ }^{1}$ was the primary champion of international peace. It was nominated for the Nobel Peace Prize in 1913, and its candidacy was favorably held until 1914. No pacifist organization could compare with the International, either in size or scope of activity (Haupt, 1972, p. 1). The International, which was considered 'the most important anti-militarist political force in the world', declared 'war on war' and 'believed itself capable of mobilizing an army of five million organized workers in the active struggle for peace' (Haupt, 1972, p. 1). It condemned war in numerous congresses and resolutions. Yet to everyone's shock, the leading parties of the International, the German and French socialists, endorsed the First World War by voting in favor of war credits. Given the internationalist and anti-war commitments of the Second International, which will be further elaborated in this article, how are we to understand this outcome?

In this article, we will show that differences in domestic political context, particularly variation in electoral success, internal party structure and party-trade union relationships resulted in a discrepancy of policy preferences and prevented the Second International from producing a binding resolution, thus culminating in the dysfunction of this international organization. Within the Second International, we focus on French and German socialist parties, which were by far the most powerful forces in the organization (Cole, 1967, p. xii). The German Sozialdemokratische Partei Deutschlands (SPD) was the most powerful party (Huberman and Lewchuk, 2003, p. 22), both in size and in theoretical influence and next to it came the French socialist parties, namely Parti Socialiste de France and Parti Socialiste Français before their unification in 1905, and Section Française de l'Internationale Ouvrière 
(SFIO) after 1905. French and German socialist parties with their different traditions and their interaction are crucial when studying the Second International (Joll, 1966, p. 3).

In what follows, we will first provide a theoretical framework for our analysis. We will then discuss the central role of war prevention for the Second International and show how the failure to come up with an orchestrated action against war constitutes an organization dysfunction. We will then analyze how domestic factors affected the dysfunction of the Second International. Our conclusion will wrap up our findings and discuss the implications and relevance of the lessons drawn from the Second International for the contemporary debates of international organizations and peace.

\section{Domestic Politics and International Organization Dysfunction}

While international relations (IR) scholars have started to examine below the state level (such as domestic politics and institutions) and above the state level (such as international cooperation and institutions) in recent decades, fewer studies have looked at the interaction of domestic and international actors (Snidal and Thompson, 2003, p. 197) even though we can see a trend of growth in this literature.

The extant literature on domestic politics' role in the international arena provides valuable insights into understanding phenomena such as foreign policy, international conflict and cooperation, as well as outcomes in international trade policies. For instance, Robert Putnam (1988, p. 454) points to the impact of political parties on the win-sets of different countries, specifically underlining the significance of left-wing parties for the prospects of cooperation. Putnam (1988, p. 434) also avers that representatives of key interest groups enter into the decision-making mechanism at the domestic level, which in turn influence the international stance of the country. Examples of this kind include the blocking of ratification of certain international cooperation agreements in areas such as trade by domestic labor unions. Furthermore, Andrew Moravcsik (1997, p. 519) suggests that we need to disaggregate state interest in foreign policy by looking at different domestic elements such as courts, central banks, executives, regulatory bureaucracies and ruling parties. Moravcsik (1997, p. 519) avows that societal pressures transmitted by representative institutions such as interest groups alter state preferences, which in turn affect the likelihood of conflict and/or cooperation. ${ }^{2}$

The fertile ground that has begun to burgeon in the IR literature about the impact of domestic factors falls short when it comes to the subject of international organizations (IOs). Much less attention has been paid to the interaction between domestic politics and IOs. As John Mearsheimer's (1994) overview of realism's and institutionalism's stance on international institutions suggests, neither of them pays sufficient attention to the influence of domestic factors on international institutions. Realists see the state as a monolithic actor and take state power and interests in an IO as given, rather than seeing these as accumulations of different interests shaped by domestic politics. Institutionalists, on the other hand, focus on the international institutions as independent variables (Mearsheimer, 1994, p. 7), again not paying enough attention to their interrelationship with domestic politics (see also Martin and Simmons, 1998).

Even more comprehensive studies such as those by Catherine Weaver (2007) and Michael Barnett and Martha Finnemore (1999) do not pay sufficient attention to the role 
of domestic factors in IO dysfunction. In their broad review of IO dysfunction, Barnett and Finnemore (1999) come up with a typology of the sources of IO dysfunction. According to this typology, the sources can be categorized in two dimensions: '(1) whether they locate the cause of IO dysfunction inside or outside the organization, and (2) whether they trace the causes to material or cultural forces' (Barnett and Finnemore, 1999, p. 716). Barnett and Finnemore suggest that material sources can be seen as internal constraints, as is the case with the pursuit of material interests within an organization and competition among subunits over material resources, or they can be seen as external constraints, as is the case with state preferences and constraints. On the other hand, cultural factors can also be seen as internal constraints resulting from the internal culture of the organizations themselves or external constraints such as international norms.

In addition to providing a typology of the existing literature on IO dysfunction, Barnett and Finnemore (1999, p. 699, p. 715) also criticize most of the IO literature for focusing too much on the rationale of IOs and on their achievements, such as responding to collective action problems, problems of incomplete information, transaction costs and other barriers to Pareto efficiency and welfare improvement for their members, and for neglecting the actual behavior of IOs including undesirable outcomes such as their dysfunction. This lack of attention can further explain the inattentiveness to domestic factors in IO dysfunction.

While the theories overviewed by Barnett and Finnemore, as well as their own analysis of IO dysfunction, present various angles of IO dysfunction, they do not discuss the issue of how domestic factors affect the shortcomings and dysfunction of IOs. It is particularly the lack of sufficient systematic treatment of the role of domestic factors in IOs and in their dysfunction more specifically that we want to address in this article. By IO dysfunction, we mean a situation where an IO fails to pursue its primary mission(s) and goal(s). We will use the Second International to analyze the way in which domestic factors affect IO dysfunction.

\section{War, Peace and the Second International}

The failure of the Second International to come up with uniform policies and coordinate socialist parties across Europe for the prevention of war constitutes an example of IO dysfunction because it illustrates a failure to pursue the stated primary objectives. The prevention of war was indeed a central goal of the Second International (Forman, 1998, p. 68). The socialists of the Second International saw the organization as 'an instrument for peace, fraternity and solidarity between the workers of all nations' and took upon itself the task of opposing war, which it believed it could achieve (Milner, 1991, p. 1).

Opposition to the 'imperialist war' was a constant element of the International congresses. Anti-militarist resolutions and condemnations of colonialism were frequent (Davis, 1973, p. 129). From the early congresses onward, the Second International agreed to transform the celebration of May Day from a demonstration in favor of the eight-hour day to a worldwide peace rally (Stargardt, 1994, p. 67). In the founding congress of 1889, the majority committed to avoid war by all possible means (Sasson, 1997, p. 27). The Stuttgart Resolution on Militarism and International Conflict that was adopted at the Stuttgart Congress (1907) stated: 'The proletariat, which contributes most of the soldiers and makes most of the material sacrifices is a natural opponent of war which contradicts its highest 
goal - the creation of an economic order on a Socialist basis which will bring about the solidarity of all peoples' (Braunthal, 1967, p. 361). The Copenhagen Congress (1910) and the Basel Congress (1912) were further examples of anti-war international socialist solidarity (Kirby, 1986, p. 4). As late as the end of July 1914, socialists were calling for peace demonstrations (Stargardt, 1994, p. 128). Despite disagreements over tactics, French and German socialists agreed it was necessary to take measures to prevent war (Haupt, 1972, pp. 40-1). The SPD and SFIO were seen as 'the most likely nay-sayers' to the war credits in their parliaments on 4 August 1914 (Hamilton and Herwig, 2003, p. 15) and few people in the Second International would have believed that these two parties could have voted in favor of these credits (Herreros, 2003, p. 326).

Despite the aim of preventing war, the Second International failed to produce a uniform action against the war, thus resulting in IO dysfunction. Leszek Kolakowski (1978, p. 28) calls this the greatest defeat in the socialist movement's history. Sheri Berman (2012, p. 598) also stresses that socialism failed in 1914 since it was unable to 'exert influence over political development commensurate with membership numbers or electoral support'. This unexpected failure depressed socialists (Kolakowski, 1978, p. 27) and fascinated historians (Stargardt, 1994, p. 127).

Before we turn to the domestic sources of this failure, some clarification might be helpful. By saying that the Second International was primarily internationalist and antimilitarist, we do not dismiss the influence of nationalism on the masses or the socialist leadership. Nationalism, if not ignored completely, was generally given a secondary role among socialists. Nationalism was judged vis-à-vis its contribution to the revolutionary potential (Stuart, 2006, p. 74) and whether it would assist the socialist cause (Forman, 1998, pp. 167-8; Schwarzmantel, 1991, p. 71). Yet scholars have also pointed to the socializing impact of schools, the army and the press (Roth, 1963, p. 220) as well as the national welfare system (Stuart, 2006, p. 5), which spread the internalization of national identity even to the working class and, to an extent, to the socialists (see also Roth, 1963).

Nevertheless, patriotism cannot explain the support given for the war credits immediately before the First World War. Even if patriotism took hold among socialists, it was not seen to be in contradiction to the Second International's primary commitments. There is generally a uniform view on the internationalism and anti-war character of the Second International. As Susan Milner (1991, p. 1) argues, by 1914 internationalism was associated with labor and socialist movements, which was reflected at an institutional level in the Second International. More specifically, Robert Stuart (2006, p. 90) claims that SFIO's idea of nationalism was compatible with internationalism. It was based on coexistence and mutual respect rather than 'the chauvinism, racism, and militarism of the degenerate bourgeoisie' (Stuart, 2006, p. 90).

In this vein, scholars of the Second International reject the view that socialist parties' support for the war effort should be interpreted as the victory of nationalist fervor over internationalism. Jeffrey Verhey (2000, p. 167), for instance, shows that the working class was by no means enthusiastic about the war. Even Paul Miller (2002, p. 204), who thinks that anti-militarism in France was mostly for domestic political purposes, acknowledges the dominance of anti-war sentiment in France among socialists, and the working class in general, just before the war. Claiming that anti-militarism was becoming more and more a 
means to prevent the war as it was approaching (Miller, 2002, p. 207), Miller (2002, p. 203) states that 'from the onset of the July crisis to the outbreak of the hostilities, socialists, syndicalists, and anarchists engaged in an eleventh-hour frenzy of antiwar activism that made them the most outspoken force for the peace in the nation'. Similar arguments are made by Nicholas Stargardt (1994, p. 142) regarding the SPD's impressive war demonstrations on 28 and 29 July. Finally, Kevin Callahan (2010, p. 295) notes that 'by and large, European workers and socialist parties met the war ... with resignation, not jubilation. And prior to receipt of mobilization orders or voting on war credits, they were the most outspoken and active force against the impending world-wide conflagration'.

Given this socialist outlook, only defensive wars were justifiable (Davis, 1973, p. 104; Miller, 2002, p. 5; Stargardt, 1994, p. 155; Stuart, 2006, p. 77). Again, this does not, on its own, explain the endorsement of the First World War. We need to understand the conditions that facilitated the perception of the war as defensive by German and French socialists. We find that this was a result of a lack of commitment to and trust in mutual action on both sides. We can understand this by looking at the interactions between French and German socialists just before they declared their support for the war. Even after Russian mobilization, the SPD's co-chairman Hugo Haase refused to support the war effort but he accepted it on 4 August 1914 in the Reichstag on the grounds that it was a defensive war (Stargardt, 1994, p. 49). We think that issues of coordination with other socialist parties, particularly the French, also need to be added to the calculation of the perception of the war as defensive and inevitable. We need to analyze each party's response in relation to the others.

During the internal debates in the party after Russia gave mobilization orders on 31 July 1914, the SPD also wanted to get a sense of what the French socialists were going to decide. Hermann Müller was sent to Paris. When he returned on 3 August, he reported to the German party caucus that the French would probably vote in favor of war credits. Stargardt (1994, p. 144) points out that this was a blow to the advocates of a 'no' vote such as Hugo Haase, Georg Ledebour, Paul Lensch and Wilhelm Liebknecht. On the other side, on the eve of the war, Léon Jouhaux, leader of the Confédération Générale du Travail (CGT), met Carl Legien, who was the leader of the German union federation (ADGB) and asked him what the German workers were prepared to do about the approaching war. As we learn from Horace Davis (1973, p. 107), 'according to Jouhaux's account, Legien met this question with silence. Jouhaux returned; war was declared; Jouhaux joined in its support and so did the French workers'. As these examples show, the lack of a clear road map and a plan to which both sides could commit themselves resulted in confusion and perceived threat on both sides, which helped to justify the idea that war was not preventable and defense was necessary. Further, Georges Haupt (1972, p. 180, p. 217) also points to the lack of concrete measures, directives and joint and coordinated tactics on behalf of the German and French socialists that led to confusion, leaving them to act as their leaders thought best.

We will now turn to the domestic sources of the lack of a clear plan and commitment among the members of the Second International. We will trace how the differences in domestic politics affected the attitudes and actions of the SPD and SFIO in Germany and France, respectively, within the Second International, resulting in the failure to coordinate on a united policy against the approaching world war. 


\section{'Second International' Explored}

In one of the very few and best known treatments of the Second International in the international relations literature, Kenneth Waltz (1959) states that as the war approached, socialist party leaderships acted patriotically, framed the approaching war as defensive for their countries, and failed to create a united front in opposition to the war. Waltz (1959, p. 147) holds that the divergence of interests of different socialist parties prevented the united action of the international socialist organization. Waltz sees these divergent interests as exogenous and does not explain how they are shaped, where they come from, how they are developed or why they differ. With the exception of a brief reference to the political concerns of the German social democrats (Waltz, 1959, p. 135), he does not examine what domestic concerns shaped the interests of the socialist parties. As is often the case with approaches to the actions of states in the international arena, Waltz takes parties as unitary actors and does not consider the interdependence between socialist parties and voters, party membership and trade unions. He does not engage in a discussion of how these domestic actors had a constitutive impact on the interests of the socialist parties. This is problematic because, as Alexander Wendt (1999, p. 35, emphasis in original) suggests in the case of interests, 'exogeneity in theory is tacitly transformed into an assumption of exogeneity in reality', which diminishes the explanatory power of Waltz's account of the failures of the Second International.

As opposed to Waltz's focus on national party interests, Francisco Herreros (2003) argues that the fact that the French and German socialists voted for war credits should not be taken as a result of chauvinist preferences of socialist leaders. ${ }^{3}$ Rather, he holds that socialist parties were trapped in a coordination problem that they could not solve. They voted the way they did, even though they were pacifists and did not want war, because they could not coordinate themselves in a joint negative vote. Herreros uses game theory in his analysis and thereby tries to show that both parties thought that the other side was going to vote for war, so they voted for war, even though they were against war and worked until the very end to stop it. Even though Herreros is right that the SPD and SFIO faced coordination problems and failed to coordinate in a joint negative vote against war, his analysis is not sensitive to the context of the cases. He analyzes both cases in the same manner and fails to consider how domestic differences in the two cases caused a discord in the Second International and resulted in a failure to coordinate. His approach does not acknowledge the embedded differences resulting from two different contexts. As a result of this, he concludes that lack of information, something that could have been overcome, prevented coordinated action in the Second International from taking place, rather than embedded factors resulting from different domestic contexts.

In order to show the domestic embeddedness of the SPD's and SFIO's policies and their failure to commit to a joint action to oppose the war, we will show how the interests and actions of the socialist parties that acted under the Second International were shaped by the level of electoral support, internal party and membership structure and the partytrade union relationship, focusing on the German and French socialist parties. Although these factors do not provide an exhaustive list of domestic forces that exerted influence on the member parties of the Second International, they illustrate very well how these 
parties were constrained domestically by various structural, institutional and organizational factors. We will demonstrate that the issue of taking revolutionary and extra-legal measures, such as a general strike in order to prevent war, was very much influenced by these domestic considerations. As a result, we hope to show that national issues could not be detached from the socialist movement, precisely because parties were not independent from the domestic system in which they operated and could not be indifferent to it if they wanted to survive.

\section{Dependency on the Electorate}

With the introduction of universal male suffrage, parties became more and more responsive to the needs and preferences of the people (Joll, 1966, p. 5). However, the support base and reliance on the electorate were very different in the French and German cases. The difference in the electoral success of the German and French socialist parties affected their motivations and actions both in domestic politics and in the Second International. German social democrats enjoyed a much broader electoral success than their French counterparts. Although the French socialists attributed value to a certain extent to the support of the people, there was little hope of electoral victory in France (Reberioux, 1983, p. 16), compared to Germany. While the German SPD won about one and a half million votes and 35 seats in the 1890 elections, only seven members of various shades of socialism were returned to parliament in the 1889 elections in France (Joll, 1966, p. 17). The stronger the support of the electorate and hope for electoral victory, the more the parties responded to the demands of the people. With electoral concerns in mind, in the campaigns for the 1912 elections the SPD made very little reference to anything except the domestic reforms with which the ordinary voter was concerned, and it fought the election as a party interested in domestic reforms (Joll, 1966, p. 146). ${ }^{4}$

The level of electoral support also influenced the receptiveness of socialist parties to the political system under which they operated. As a result of the successful election result, German socialists, in general, became convinced that electoral success would bring the socialist revolution.

As G. D. H. Cole (1967, p. 267) suggests:

[SPD] cherished the hope that steady persistence in its propagandist and organizing activities would in due course bring it the backing of a clear majority ... in the Reichstag ... [The party] did believe that the Kaiser and his ministers would find it impracticable to govern against the Reichstag, and that ... [the party] would be in a position to enforce a great transformation in the entire system of government, whether or not it were forced to make use of unconstitutional means in bringing the change about. This caused it to postpone the possible need for acting unconstitutionally until after it had won over a majority of the people and got the authority of the Reichstag in its hands.

As we have seen, the SPD had a stake in remaining legitimate in the electoral system and the party came to view this as compatible with their socialist goals as their electoral success made them confident they could change the system through electoral means.

The SPD leadership had also learned from history that opposing nationalistic decisions resulted in loss of votes for their party. After the 1870 Franco-German war and the defeat 
of France, German social democrats opposed the annexation of Alsace-Lorraine by Prussia. They called for demonstrations and produced manifestos. The loss of mass support for the SPD was enormous. Its membership was 13,147 from 113 localities at the Stuttgart Party Congress (1870) and fell to 6,225 from 81 localities in the Dresden Party Congress (1871) (Braunthal, 1967, p. 170). The same happened to the SPD in 1906 when it refused the approval of new credits for financing the campaign against insurgents in African German colonies. The Reichstag was dissolved and the party faced an electoral defeat (as a result of chauvinistic and nationalist propaganda) in 1907 (Hottentot elections), with 79 seats reduced to 43 and the percentage of votes from 32.6 to 29.5 (the first defeat since 1884) (Braunthal, 1967, p. 313). After these elections, the party leadership was 'more determined than ever to clear Social Democracy of the "slanderous" campaign charges that it was anti-national' (Schorske, 1955, pp. 61-75).

These concerns were reflected in the SPD's behavior in the Second International long before the First World War. For instance, during the Copenhagen Congress (1910), on the issue of a general strike, German delegates argued that:

to make any reference to strike action in face of war, even by mentioning as a matter which the International had undertaken to consider, might lead to prosecution of Social Democratic Parties of those countries for treasonable practices and might give the governments an opportunity to suppress them and confiscate their resources (Cole, 1967, p. 84).

The difference in electoral support and in what parties had to lose influenced the diverging approaches of German and French socialists on what measures to take against war. While French socialists pushed for taking more drastic measures against the war, German socialists in general were more inclined to be less confrontational and refrained from taking binding decisions in the Second International that would require every member country to organize general strikes and insurrections against war attempts in their countries.

\section{Internal Party Structure and Party Dynamics}

The internal party dynamics, especially certain effective groups in the party, need to be considered when examining how the interests of a party were shaped. In addition, the general tendency and preference of socialist groups outside the party are also important because parties try to incorporate these groups - or at least make the party more appealing for their supporters - and transfer them to their own party. In both ways, the parties aim to increase their support base and political power.

In contrast to the German SPD, the French socialist party system was fragmented in nature and the accomplishment of its unity came very late. While the SPD was established as a united party in the Eisenach Congress in August 1869 (Braunthal, 1967, pp. 116-7), ${ }^{5}$ it was only in April 1905 that the two French groups Parti Socialiste de France and Parti Socialiste Français met in a conference in Paris and formed the united party Section Française de l'Internationale Ouvrière (SFIO) (Joll, 1966, p. 106).

The SPD was not only good at and well organized in conducting elections, vote winning and influencing legislation, but it also had its own women's movement, youth movement and publications for each section of the working class (Joll, 1966, p. 65). The French Marxists, however, were fighting both with the reformists in the party and with revolu- 
tionary syndicalism from the early 1890s onwards, and they could not establish a monolithic party model as in Germany (Joll, 1966, p. 62). The fact that socialism in France was grounded on diverse socialist traditions such as utopian idealism, anarchism and the tradition of insurrection also prevented the French socialists from reaching the unity enjoyed by German socialists (Joll, 1966, p. 14).

In 1882, a split occurred at the Étienne Congress in France and two rival parties emerged. That year, Jules Guesde's Parti Ouvrier was fully established. But against him the Possibilists headed by Paul Brousse formed the Parti Ouvrier Socialiste Révolutionnaire in the same year. Both parties had their own trade union movements (Cole, 1967, p. 3). By 1889, the French socialist and labor movement was divided into contending factions. Not only rival parties but also rival trade union movements were created (Cole, 1967, p. xii). The Possibilists, led by Brousse, defended 'gradualist socialism which laid stress on local control' and advocated local autonomy. This idea was accepted by the majority and Brousse retained control of the new party. The Guesdists (headed by Guesde and Paul Lafargue), on the other hand, formed their party based on a centralized, Marxist model. While the Guesdists emphasized the primacy of the political party, the Possibilists 'wished to act as the agents of the trade unions' (Cole, 1967, pp. 326-7) - a point that will also be important when discussing the party-trade union relationship in France.

The two French parties came together in 1905, and stayed together with Jean Jaurès as leader and Guesde 'as a grumbling second-in-command' (Cole, 1967, p. 59). From the party unification to his assassination in 1914, Jaurès was the outstanding figure of his party and in the congresses of the Second International (Cole, 1967, p. 373). He also played an enormous role in the unification of French socialists and in holding them together after their unification. The concept of unity of socialists and trade unions was the first principle of his socialist doctrine. For instance, Jaurès persuaded the majority of party members, against the Guesdists, to give their support to the policy of general strike, because he saw that 'to oppose it would mean tearing the working class asunder' (Cole, 1967, p. 374). The unification formula in 1905 reflected a compromise between the reformists and the anarcho-syndicalists (Lichtheim, 1968, p. 35). This affected the policies followed by the party and differentiated it from the SPD, making French socialists more prone to accept general strike as a strategy than the German socialists.

In Germany, the anarchists had been eliminated as an influence on mass opinion to a great extent (Cole, 1967, p. 13) whereas in France anarchism in different forms (from 'propaganda by deed' to anarcho-syndicalism) was still an active force. The anarcho-syndicalists were especially difficult to tame because they looked at ways of struggling outside the political realm. In France (unlike Germany) there were always 'powerful forces that were unready to accept political leadership from any source ... and looked for inspiration to trade unionism rather than to any political party' (Cole, 1967, p. 14). The fact that there was less faith in electoral victory compared to that in Germany, as mentioned above, also sharpened this position.

Since French socialist leaders lacked the party discipline that the Germans enjoyed, they had to give more concessions to hold the party and socialist movement together. In order to gain the support of people who had syndicalist and anarchist inclinations, the party often adapted its strategies accordingly. This is also one reason why French socialists supported 
more radical and revolutionary means than their German counterparts during the Second International.

\section{Trade Union-Party Relationship}

The third influential domestic factor that affected the workings of the Second International is the different nature of trade union-party relationships in the two countries. For socialist parties, the trade unions have a special role in terms of both the socialist aim of increasing workers' welfare and member recruitment for the party. Therefore, the dominant ideological tendencies within the trade unions directly affect the parties' general stance. Moreover, the more trade unions are autonomous from the party and less willing to accept political leadership, the more the parties have to give concessions to these unions in order to hold them under their lead.

These differences between French and German socialist parties in their relations with trade unions started from the very beginning in that the origins of trade unions in France and Germany were different. The first socialist party in France grew out of the trade unions, whereas in Germany the SPD was created before most of the trade unions. As Bernhard Moss (1976, p. 136) argues, where political socialism antedated trade unionism, as was the case in Germany, the unions were created and dominated by political socialists, unlike in France where the party was created by trade unions.

In addition to this, German trade unions were much more centralist - a point that can be seen as an influence of the party - than French syndicats (Moss, 1976, p. 27). During the Second International, the SPD was not only fully unified but also had effective command over the German trade union movement. The trade unions, except for the relatively small Christian group or those with Liberal (Hirsch-Dunker) support, were firmly disciplined under social democratic leadership and obediently followed their lead (Cole, 1967, p. xii). Under Karl Legien's leadership, they were firmly allied with the SPD and their representatives were part of the socialist delegation (Cole, 1967, p. 18). At the Second International, German trade unions were represented as part of the social democratic delegation (Cole, 1967, p. 365).

We can see a clear contrast between France and Germany in terms of party and trade union relationship. In France, even after the unification, trade unions maintained their independence from the party and were by no means committed to follow its lead (Cole, 1967, p. xii).They united under the trade union organization, Confédération Générale du Travail (CGT) (Moss, 1976, p. 146), ${ }^{6}$ which 'proclaimed against the parliamentary policy of the Unified Socialist Party their creed of Syndicalism and Direct Action' (Cole, 1967, p. 323).

Again in contrast to the German case, where the socialist movement presented a solid front during the Second International congresses, the French delegations were always sharply divided, and contained a strong anarchist element (Cole, 1967, pp. xii-19). The French took the issue of trade union independence so seriously that they read a declaration expressing their adherence to the principle of complete trade union independence at the Stuttgart Congress (1907).

Not only the relationship between trade unions and the party but also the dominant trade union mentality was different in France and Germany. As a general characteristic, German trade unions were in the majority reformist and anti-revolutionary (Moss, 1976, 
p. 27). They saw trade unions as 'essentially bargaining bodies for the protection of their members' interest under whatever economic system they had actually to face'. They would stay independent from the revolutionary function, which according to them belonged to the party, in order to serve better 'their day-to-day work within the limits set by law' (Cole, 1967, p. 365). They also viewed confining themselves within the limits of the laws as crucial because they wanted to avoid suppression and to serve their members' immediate economic interests. In accordance with this, they were closer to the reformists/revisionists in the party. The leaders of the trade unions and reformist party members overlapped and there was a close connection between reformists in the party and the free trade unions (Maehl, 1952, p. 26). On the other hand, the French trade unions' rank and file were typically more revolutionary than the socialist party leaders (Moss, 1976, p. 138).

Of course, there were specific reasons for the differences between German and French trade unions. German trade unions were concerned about a general strike because their member workers historically lost a lot during these strikes. Employers exploited the May Day strikes 'as an occasion for counterattacks on the unions'. The number of workers locked out after May Day of 1905 was 6,404. In 1906, a minimum of 32,000 were locked out in Berlin, Hamburg, Leipzig and Breslau alone. The trade unions were so concerned about this that in 1904, at the Amsterdam Congress, German trade union representatives tried to change the May Day observance from a strike to an evening demonstration (Schorske, 1955, p. 91). Moreover, German unions gained much within the legal system. They were successful in increasing members' wages and reducing hours of work, with the help of economic prosperity in Germany (Maehl, 1952, p. 26). German trade unions also accumulated funds and developed extensive benefit services, thereby growing stronger and wealthier (Cole, 1967, p. 305). As a result, they focused on the immediate material interests of workers within the existing system rather than adopting radical policies that would endanger their gains.

French trade unions, on the other hand, had been able to use the strikes successfully. Out of the total labor force of more than 7 million, workers could already give shocks to sections of the economy and produce those short periods of paralysis which have remained their tactics, with increased, if never final, effectiveness, until the present day. Thus, in the years after 1907, a postal strike, a railway strike and numerous others shook the economy and frightened the bourgeoisie (Joll, 1966, p. 133).

Because their experiences showed that general strikes paralyzed the French economy, syndicalists believed in the inevitable success of a general strike. According to them, a general strike 'would turn itself into a revolution leading to the overthrow of capitalism and assumption of power by the victorious proletariat'. This issue was first discussed in 1885-6 and then preoccupied French anarchists and revolutionary trade unionists in each successive congress (Cole, 1967, p. 330). The resolution of the Fédération Nationale des Syndicats, as early as in 1888, argued that a general strike alone 'can lead the workers towards their emancipation' (Cole, 1967, p. 334).

The fact that the SPD was more unified and was free of both syndicalist trade union influence and anarchist movements, and that the opposite was true in the French case, where trade unions were independent and more radical than the party leadership, was explicitly reflected in the debates between French and German delegates in the Second 
International about using general strike as a strategy for gaining rights, establishing the ideal system and preventing wars. On May Day 1890, Germans refused the idea of general strike (Joll, 1966, p. 53). ${ }^{7}$ Sixteen years later, in the resolution of 1906 and at the Stuttgart Congress in 1907 on the proposal to prevent war in Europe, the SPD's attitude did not change. French socialists, on the other hand, pressed for the acceptance of general strike as an effective tool on all of these occasions. This difference in attitude was closely related to the socialist organization in both countries, as well as the party-trade union relationship.

As previously mentioned, France had a strong syndicalist movement, which was also the dominant view of the trade unions. French socialists had to give concessions to the syndicalist ideals of direct action in order to cooperate with them and preserve and strengthen the links between the party and the union - mainly with the CGT, the strong militant union (Moss, 1976, p. 146). ${ }^{8}$ With these motivations, the SFIO decided to support all means possible to prevent war in Europe, 'from parliamentary intervention and public agitation to the general strike and armed uprising' (Braunthal, 1967, p. 335). ${ }^{9}$

The German side, confident about its organizational unity and domestic legislative influence, relied on tactics operating within the existing political system (Maehl, 1952, p. 31). ${ }^{10}$ General strike and radical policy were seen as threatening to the party, in terms of both mass support and state repression. In fact, a secret meeting between party leaders and trade union leaders in Germany occurred in 1906, where trade union leaders expressed their concerns about a general strike. As a result, they decided against it (Cole, 1967, p. 308). Their proposal was, of course, different from the French one and stated 'whatever means most appropriate', carefully avoiding a radical policy (Braunthal, 1967, p. 335). Since the French and Germans could not agree, either in 1906 or 1907, a careful compromise was reached between them, leaving decisions of action to each country and committing no one to anything (Joll, 1966, p. 132):

The Congress confirms the resolutions adopted by previous international congresses against militarism and imperialism and declares once more that the struggle against militarism cannot be separated from the Socialist class struggle in general ... The International is not able to determine in rigid forms the anti-militarist actions of the working class which are naturally different in different countries and for different circumstances of time and place. But it is its duty to coordinate and increase to the utmost the efforts of the working class against war ... If a war threatens to break out, it is the duty of the working classes and their parliamentary representatives in the countries involved, supported by the coordinating activity of the International Socialist Bureau, to exert every effort in order to prevent the outbreak of war by the means they consider most effective, which naturally vary according to the sharpening of the class struggle and the sharpening of the general political situation. In case war should break out anyway, it is their duty to intervene in favor of its speedy termination and with all their powers to utilize the economic and political crisis created by the war to rouse the masses and thereby to hasten the downfall of capitalist class rule (Braunthal, 1967, pp. 361-3). ${ }^{11}$

According to Carl Schorske (1955, p. 85), the Stuttgart resolution was the outcome of a triple alliance between party revisionists, party executive and trade unionists in Germany. He argues that German radicals were pushed back on the questions of war and colonialism. This did not change at the Copenhagen Congress (1910). The resolution regarding the prevention of war stated that: 
the Congress recognizing that it would be difficult to formulate a model instruction for the carrying out of the resolutions of the International Congresses, declares that it is necessary to leave to the national parties the power to choose the form of action and the opportune moment (Cole, 1967, p. 86).

By the time the First World War was approaching, the Second International had failed to agree on a single form of action that would unite the socialists of Europe against war. Contrary to what one would expect from an international organization such as the Second International, it failed to produce trust among its members and foster the confidence that each socialist party would prioritize socialist ideals over the nationalist interests of their countries. In this chaotic environment to which the Second International was unable to bring certainty and predictability, socialist parties acted along their national lines. The reluctance of German socialists to take measures to oppose the war heightened French concerns about German aggression since French socialists thought that German socialists would not take the necessary steps to stop their country from going to war. Once the war began in 1914, not only German socialists but also French socialists voted for war credits in their parliaments on 4 August.

\section{Conclusion}

In this article, we have shown the role that domestic factors played in the failure of the Second International. We have demonstrated that structural, organizational and institutional factors at the domestic level constrained the actions of parties at the international level, which in turn led to IO dysfunction. We illustrate that the fact that German social democrats enjoyed more electoral support, were more united and had eliminated anarchist movements from early on, and that they had trade unions under control overall, shaped the interests of the SPD in such a way that they supported more moderate policies against war and wanted to leave the decision on such policies to member socialist parties of the Second International. French socialists, on the other hand, were fragmented and the radicals were strong. With regard to trade unions, French unions were more revolutionary than the party leaders and they acted autonomously from the party. Moreover, while German trade unions had suffered from a general strike, French trade unions usually had gained from general strikes, which made the French unions more inclined to accept such radical tactics.

These domestic differences mattered because they had vital consequences for the prospects of coordinated action and the commitment to decide on binding action in order to prevent war from breaking out. While the SFIO and French socialists pressed for a general strike, to be held by all socialist members of the Second International simultaneously, as the only means to stop war, such a proposal was not openly accepted by the SPD (Hostetter, 2007 [1950]). French socialists reasoned that a general strike could only be successful in preventing war if it occurred concurrently in all countries concerned. They repeatedly pushed for the other national sections to sanction a general strike against war at the congresses of Stuttgart (1907), Copenhagen (1910) and Basel (1912) (Hostetter, 2007 [1950], p. 30). The French attempt to achieve a more radical and binding policy resolution by the Second International was prevented by the German social democrats. 
For French socialists, the hesitancy of the SPD to commit itself to such binding radical policies was unacceptable. They regarded this hesitancy as a lack of pacifist ardor. French socialists were impressed by the size and organization of the SPD: 'Seen from beyond the German frontier, the Social Democracy had little if any reason to reject a revolutionary program to prevent war' (Hostetter, 2007 [1950], pp. 49-50). The picture was perceived differently on the other side of the border, however. From the SPD's point of view, the threat of extra-legal methods, especially violent ones such as general strike and insurrection, and even the appearance of contemplating such measures, carried the risk of an efficient and summary suppression (Hostetter, 2007 [1950], p. 50).

Overall, the fact that there was not a binding road map for socialist parties and that there was no common trust that parties would take all drastic measures to ensure that war did not break out, heightened panic and concern in the parties. Under these circumstances, in early August 1914, the socialist parties of France and Germany were left with no previously concerted plan of action against the threat of war (Hostetter, 2007 [1950], p. 31). This resulted in the total collapse of the Second International and the failure to oppose the war.

If we turn to Herreros' (2003) argument outlined earlier, we can say that while we agree with him that coordination and commitment problems and lack of trust were instrumental in the Second International's failure to commit to orchestrated measures against war, or to vote against war credits in parliament, we argue that not only lack of information among the socialist parties but also domestically embedded differences should be taken into account if we are to understand the reasons behind the failure of the Second International.

The Second International stands as an excellent case study, in which we see that IOs cannot be thought to be separate from domestic concerns, even in the most extreme cases where one would expect domestic particularities not to become an issue. The case at hand shows us that domestic actors should be incorporated in the IO literature more ambitiously and meticulously in order to raise its explanatory power. Differences at the domestic level can create unbridgeable diversity in the ideas and interests of actors within the international arena to the extent that they cause organization dysfunction. As a result, we find that studies on IO dysfunction cannot be complete without taking into account the impact of domestic actors and related domestic factors on international organizations.

The scope of the argument exceeds non-governmental organizations and parties that act as non-state actors as is the case with the member parties of the Second International. Governments comprise parties, which are bound by similar domestic factors to the socialist parties of Europe, such as electoral success, party base and internal party structure. Hence our arguments regarding the influence of such factors on IOs and their dysfunctions open a possible research agenda for the study of IOs where participation is at the state level. In this way, instead of focusing only on the differences of interests among different countries, we can examine further the causes of these differences by looking at how interests and motivations are conditioned at the domestic level. We can then evaluate how these domestically embedded differences affect the functioning of different actors within an IO and how they affect the prospects of coordination.

Finally, this article has important lessons for contemporary efforts to prevent war through international measures. As we have seen, international socialism 'found refuge in short-term solutions and compromises, thereby avoiding the issues that would have forced them to take 
a stand' (Haupt, 1972, p. 219). This had vital consequences for the future of the Second International and its inability to provide a road map for its members on the eve of war. As this case demonstrates, glossing over domestically generated differences by using vague language in the decisions and resolutions of international organizations might give comfort to all parties involved in the short run but does not lead to trust or to a road map in the long run. This can teach us important lessons for organizations such as the UN. After all, as Callahan (2010, p. xix) argues, 'socialist congresses were a model and vision of the socialist future, wherein nationalities co-exist in a peaceful international framework, a possible forerunner to the League of Nations and United Nations'. Taking this into account, we need to emphasize the role of clearly written decisions that lay out the course of action to be followed for international organizations.

(Accepted: 25 August 2012)

(Published online: 30 July 2013)

\section{About the Authors}

Meral Ugur Cinar is Assistant Professor at Bilkent University, Ankara. Previously, she was a Mellon Interdisciplinary Postdoctoral Fellow at the New School for Social Research in New York. She received her PhD in Political Science from the University of Pennsylvania in 2012. She is also a National Center for Institutional Diversity (NCID) Exemplary Diversity Scholar and co-author of an article that received the Sabanci International Research Award. Her research interests include nationalism, citizenship, collective memory, constitution making, social movements, identity politics and cultural studies. She has regional expertise in the Middle East and Europe. Meral Ugur Cinar, Department of Political Science and Public Administration, Bilkent University, Ankara, Turkey. email: meral.ugur@gmail.com

Kursat Cinar is a Political Science PhD candidate at the Ohio State University (OSU). He was a Fulbright scholar during his Economics Master's degree at New York University. He also holds a Master's degree in Political Science from the OSU. Cinar is interested in comparative political economy, development and comparative political institutions. Specifically, he is interested in patronage politics, politics of poverty and inequality, and socio-economic and political determinants of democracy. His area foci are Europe and Latin America. Kursat Cinar, Department of Political Science, Ohio State University, 2140 Derby Hall, 154 N. Oval Mall Office 2031, Columbus, OH 43210, USA; email: cinar.3@osu.edu

\section{Notes}

The authors would like to thank Julia Lynch, Alexander S. Thompson, Alexander Wendt and two anonymous reviewers for their valuable comments and constructive suggestions.

1 The Second International (1889-1914) was a socialist organization which by 1912 represented the socialist and social democratic parties of all European countries, the US, Canada and Japan. Its headquarters was in Brussels and its congresses were held in Paris (1889 and 1900), Brussels (1891), Zurich (1893), London (1896), Amsterdam (1904), Stuttgart (1907), Copenhagen (1910) and Basel (1912).

2 In addition, see, for example, Cowhey, 1993; Katzenstein et al., 1998, on domestic politics and international political economy; Fearon, 1994; Schultz, 1998, on domestic political competition and the escalation of international crises; Huberman and Meissner, 2010, on diffusion of social policy vis-à-vis local and international forces; Milne, 2011, on domestic constituencies and international negotiations; Risse-Kappen, 1991, on public opinion and foreign policy; Schultz, 1999, on domestic political institutions and military disputes; and Sprinz and Vaahtoranta, 1994, on domestic factors and international environmental negotiations.

3 Hostetter (2007 [1950], pp. 47-8) also rejects the argument that the SPD used the Second International as an instrument of German nationalism and argues that the SPD had a sincere desire for peace. According to him, the majority of the party considered war as a threat to the life of social democracy. The SPD held the opinion that in Germany a war - assuming a successful one could only strengthen the government, the military and reaction in general but not social democracy and its ideals.

4 Although revisionism was rejected as a party ideology and loyalty to Marxism was declared, it can be said that it became predominant in practice, especially with regard to the importance given to the electoral process.

5 At the Eisenach Congress, the General Association of German Workers, founded by Ferdinand Lassalle in 1863, and the Association of German Workers' Organization, led by Wilhelm Liebknecht and August Bebel, came together to form the Social Democratic Party of Germany.

6 In 1902, Fédération Nationale des Bourses du Travail merged with CGT, under the name of CGT. 
7 In 1889, the German socialists included in the congress resolution a clause to leave every country free to decide whether to participate in the international May Day manifestations.

8 Between 1901 and 1909, the CGT was directed by a coalition between anarchists and revolutionary socialists.

9 This is a resolution by Jaurès and Vaillant.

10 In fact, the SPD really believed that it could do something under the existing order - especially after 1911, when the likelihood of a European war was felt to be great. The party leadership therefore used all legitimate non-militant means to promote pacifism. 'In mass meetings, in international conferences, in Reichstag debates over increases in the armed forces, in handbills, articles, and formal protests, the pacifist and orthodox majority of the SPD denounced war' (Maehl, 1952, p. 31).

11 Excerpt from the Stuttgart Resolution (1907).

\section{References}

Barnett, M. N. and Finnemore, M. (1999) 'The Politics, Power, and Pathologies of International Organizations', International Organization, 53 (4), 699-732.

Berman, S. (2012) 'Book Review of Demonstration Culture: European Socialism and the Second International, 1889-1914 by Kevin J. Callahan', American Historical Review, 117 (2), 598.

Braunthal, J. (1967) History of the International 1914-1943. New York: Praeger.

Callahan, K. J. (2010) Demonstration Culture: European Socialism and the Second International, 1889-1914. Leicester: Troubador.

Cole, G. D. H. (1967) A History of Socialist Thought, Volume III. Part I: The Second International 1889-1914. London: Macmillan.

Cowhey, P. F. (1993) 'Domestic Institutions and the Credibility of International Commitments: Japan and the United States', International Organization, 47 (2), 299-326.

Davis, H. B. (1973) Nationalism and Socialism: Marxist and Labor Theories of Nationalism to 1917. New York: Monthly Review Press.

Fearon, J. D. (1994) 'Domestic Political Audiences and the Escalation of International Disputes', American Political Science Review, 88 (3), 577-92.

Forman, M. (1998) Nationalism and the International Labor Movement: The Idea of the Nation in Socialist and Anarchist Theory. University Park PA: Pennsylvania State University Press.

Hamilton, R. F. and Herwig, H. H. (eds) (2003) The Origins of World War I. Cambridge: Cambridge University Press.

Haupt, G. (1972) Socialism and the Great War: The Collapse of the Second International. Oxford: Clarendon Press.

Herreros, F. (2003) 'The Dilemma of Social Democracy in 1914: Chauvinism or Social Dilemma', Rationality and Society, $15(3), 324-44$

Hostetter, R. (2007 [1950]) 'The SPD and the General Strike as an Anti-war Weapon, 1905-1914', The Historian, 13 (1), $27-51$.

Huberman, M. and Lewchuk, W. (2003) 'European Economic Integration and the Labour Compact, 1850-1913', European Review of Economic History, 7 (1), 3-41.

Huberman, M. and Meissner, C. M. (2010) 'Riding the Wave of Trade:The Rise of Labor Regulation in the Golden Age of Globalization', Journal of Economic History, 70 (3), 657-85.

Joll, J. (1966) The Second International, 1889-1914. New York: Harper \& Row.

Katzenstein, P. J., Keohane, R. O. and Krasner, S. D. (1998) 'International Organization and the Study of World Politics', International Organization, 52 (4), 645-85.

Kirby, D. (1986) War, Peace, and Revolution: International Socialism at the Crossroads 1914-1918. Aldershot: Gower.

Kolakowski, L. (1978) Main Currents of Marxism, Vol. II: The Golden Age. Oxford: Clarendon Press.

Lichtheim, G. (1968) Marxism in Modern France. New York: Columbia University Press.

Maehl, W. (1952) 'The Triumph of Nationalism in the German Socialist Party on the Eve of the First World War', Journal of Modern History, 24 (1), 15-41.

Martin, L. and Simmons, B. (1998) 'Theories and Empirical Studies of International Institutions', International Organization, 52 (4), 729-57.

Mearsheimer, J. J. (1994/5) 'The False Promise of International Institutions', International Security, 19 (3), 5-49.

Miller, P. B. (2002) From Revolutionaries to Citizens: Antimilitarism in France, 1870-1914. Durham NC: Duke University Press.

Milne, D. (2011) ‘The 1968 Paris Peace Negotiations: A Two Level Game?', Review of International Studies, 37 (2), $577-99$.

Milner, S. (1991) The Dilemmas of Internationalism: French Syndicalism and the International Labor Movement, 1900-1914. New York: Berg.

Moravcsik, A. (1997) 'Taking Preferences Seriously: A Liberal Theory of International Politics', International Organization, $51(4), 513-53$.

Moss, B. H. (1976) The Origins of the French Labor Movement 1830-1914: The Socialism of Skilled Workers. Berkeley CA: University of California Press.

Putnam, R. (1988) 'Diplomacy and Domestic Politics: The Logic of Two-Level Games', International Organization, 42 (4), 427-61.

Reberioux, M. (1983) 'Party Practice and Jauresian Vision: The SFIO (1905-1914)', in S. Williams (ed.), Socialism in France: From Jaures to Mitterand. New York: St Martin's Press, pp. 15-26.

Risse-Kappen, T. (1991) 'Public Opinion, Domestic Structure, and Foreign Policy in Liberal Democracies', World Politics, 43 (4), 479-512. 
Roth, G. (1963) The Social Democrats in Imperial Germany: A Study in Working-Class Isolation and National Integration. Totowa NJ: Bedminster Press.

Sasson, D. (1997) One Hundred Years of Socialism: The West European Left in the Twentieth Century. London: Fontana.

Schorske, C. E. (1955) German Social Democracy, 1905-1917: The Development of the Great Schism. New York: Wiley.

Schultz, K. A. (1998) 'Domestic Opposition and Signaling in International Crises', American Political Science Review, 92 (4), 829-44.

Schultz, K. A. (1999) 'Do Democratic Institutions Constrain or Inform? Contrasting Two Institutional Perspectives on Democracy and War', International Organization, 53 (2), 233-66.

Schwarzmantel, J. (1991) Socialism and the Idea of the Nation. New York: Wheatsheaf.

Snidal, D. and Thompson, A. (2003) 'International Commitments and Domestic Politics: Institutions and Actors at Two Levels', in D. Drezner (ed.), Locating the Proper Authorities:The Interaction of Domestic and International Institutions. Ann Arbor MI: University of Michigan Press, pp. 197-230.

Sprinz, D. and Vaahtoranta, T. (1994) 'The Interest-Based Explanation of International Environmental Policy', International Organization, 48 (1), 77-105.

Stargardt, N. (1994) The German Idea of Militarism: Radical and Socialist Critics 1866-1914. Cambridge: Cambridge University Press.

Stuart, R. (2006) Marxism and National Identity. Albany NY: State University of New York Press.

Verhey, J. (2000) The Spirit of 1914: Militarism, Myth and Mobilization in Germany. Cambridge: Cambridge University Press. Waltz, K. (1959) Man, the State, and War. New York: Columbia Press.

Weaver, C. (2007) 'The World's Bank and the Bank's World', Global Governance, 13 (4), 493-512.

Wendt, A. (1999) Social Theory of International Politics. Cambridge: Cambridge University Press. 